\title{
„Használati útmutató” a kutatói szemléletmód kialakításához a tudásalapú társadalmak pedagógusképzésében - Könyvismertetés
}

Csíkos Csaba (2020). A neveléstudomány kutatásmódszertanának alapjai. Elte Eötvös Kiadó, p. 118, Budapest. ISBN 978-963-489-248-9

https://www.eltereader.hu/media/2020/12/web_Csikos-Csaba_Bevezetes_.pdf

\section{Flick-Takács Nikolett}

Eötvös Loránd Tudományegyetem Tanitó- és Óvóképzö Kar Neveléstudományi Tanszék

A 21. század tudásalapú társadalma nemcsak a gazdaság és munkaerőpiac terén, hanem a pedagógusoktól is egyfajta új szemlélet elsajátítását követeli meg (Csapó, 2005, 2015; Ollé, 2012). A kutatás - fejlesztés - innováció hármasában az egyetemeknek alapvető jelentősége van, amelyek alól a pedagógusképzés intézményei sem kivételek (Kraiciné, 2009). A kutatás és fejlesztés összekapcsolása azonban nem kis kihívás, hiszen a neveléstudományi gyakorlatban a tudományos eredmények csupán kis mértékben hasznosulnak (Csapó, 2020). A probléma megoldására a kutatók (és több nemzetközi jó gyakorlat, például a finneké is) a pedagógusképzés kutatás alapú formáját szorgalmazzák a hagyományos merev, kizárólag tudásközvetítésen alapuló felfogással szemben (Hercz, 2008, 2012; Csapó, 2015, 2020).

A szemléletbe jól illik Csíkos Csaba (2020) A neveléstudomány kutatásmódszertanának alapjai címü kutatásmódszertan-jegyzete, amely kifejezetten az alapszakos pedagógusképzésben tanuló kisgyermeknevelő, óvodapedagógus és tanító szakos hallgatók számára készült. A könyv müfaja tudományos ismeretterjesztés. Bár a neveléstudomány bővelkedik olyan kutatásmódszertani gyüjteményekben és szakkönyvekben, amelyek segítségével a tudományos megismerés világának kapuja előtt álló hallgatók részletekbe menően megismerhetik a kvalitatív és kvantitatív kutatási paradigmákat, hazánkban egyedülálló, hogy ennyire aktuális, tömör és informatív mü született kifejezetten a pedagógusjelöltek kutatásmódszertani tanulmányainak megalapozására. A bemutatásra kerülő mü jelentőségét az is igazolja, hogy a szerző saját több évtizedes oktatói és kutatói gyakorlatára építve mutatja be a 
neveléstudomány területén felhalmozott kutatásmódszertani szakkönyvek ${ }^{1}$ alapvető tudásanyagát, mindazt egyetlen, átfogó könyvben rendszerezve, nagy hangsúlyt fektetve a pedagógiai aspektusra.

A jegyzet összesen 120 oldal terjedelmü, amely öt tartalmi fejezetre tagolódik. Ezekben megismerkedhetünk (I.) a neveléstudományi kutatások alapkérdéseivel, (II.) neveléstudományi kutatási stratégiákkal, (III.) az adatgyüjtés és (IV.) az adatelemzés módszereivel, valamint (V.) a tudományos publikációk jellemzőivel.

A könyv terjedelme és a föbb fejezetek alapján látható, hogy a jegyzetnek nem célja a kutatásmódszertan minden szegmensének tudományos ismertetése, a pedagógusképzésben azonban funkciója vitathatatlan, hiszen célul tüzi ki az alapszakos pedagógus hallgatók kutatásmódszertani tanulmányainak megalapozását. İgy tehát elsősorban kisgyermeknevelő, óvodapedagógus, valamint tanító szakos hallgatók, valamint a neveléstudomány területén dolgozók és tanulók számára szolgál releváns és hasznos tudással a könyv. A tudásanyag átadása három szinten történik:

a) elméleti tudás szintjén a kutatásmódszertani szaknyelv megismerésével, a kutatási stratégiák, módszerek megosztásával, a mintavételi eljárások és tudományos publikáció műfajainak ismertetésével

b) gyakorlati szinten a pedagógus hallgatók tudományos kutatásában, diákköri és szakdolgozatának megírásában nyújt segítséget (V. fejezet),

c) attitüdök formálása terén a tudományos szemléletmód kialakítására törekszik a kutatási jelenségek és a pedagógiai gyakorlat összekapcsolásával, amelyhez számos gyakorlati pedagógiai példát sorakoztat fel.

Az első fejezetben az olvasó a tudományosság alapjaival, a neveléstudomány sajátosságaival ismerkedhet meg. A szerző bemutatja a kvalitatív és kvantitatív kutatási irányzatokat, a tudományos szövegek felismerésének és feldolgozásának sajátosságait, valamint a kutatás tervezésének olyan fontos mozzanatait, mint a kutatási kérdés- és hipotézis felvetés, mintavételezés és kutatásetikai alapelvek. A fejezetben gyakorlatközeli példákkal szemlélteti az elméleti tartalmi elemeket, így például az analitikusság tudományos alapelvét az olvasó pedagógiai szituáción keresztül értelmezheti, együtt gondolkodva a szerzővel: „ezek a tanulók nagyon motiváltak, és gyönyörüen olvasnak” (p. 13). A fejezet azért is hasznos a tudományos szemléletmód kialakításában, mert az imént illusztrált módon, gyakorlati példákon keresztül irányítja a pedagógusjelölt gondolkodását olyan irányba, amelyben a pedagógiai szituációkat, probléma helyzeteket kutatói szemmel kutatási problémákban tudja majd azonosítani.

A második fejezet a fóbb neveléstudományi kutatási stratégiákat tárgyalja, amely a maga tömörségével (18 oldal) gyors és egyszerủ útmutatás lehet a hallgatók számára, amikor a képzésben eljutnak arra a pontra, hogy feltegyék maguknak a kérdést: milyen müfajú szakdolgozatot írjak? Az olvasó megismerheti az elméleti és empirikus kutatások sajátosságait a neveléstörténeti

\footnotetext{
${ }^{1}$ Például: Kutatás-módszertani Kiskönyvtár sorozat
} 
kutatások, dokumentumelemzés, felmérések (longitudinális, keresztmetszeti és trendvizsgálatok), internetalapú kutatások, pedagógiai kísérletek és akciókutatások mentén.

A fejezetben találkozhatunk a már megszokott módon, mindenki számára ismerős, és időnként humoros gyakorlati példákkal is (lásd p. 41), de találhatunk utalásokat az egyes stratégiák szakdolgozati szinten történő alkalmazására, illetve megismerhetjük az egyes stratégiák alkalmazásának előnyeit és hátrányait is.

Az adatgyüjtés módszerei közül a szerző a pedagógiai kutatásokban legygyakrabban használt kérdőív-, interjú-, megfigyelés- és teszt módszereit emeli ki és ismerteti. A fejezetben az olvasó megismerheti az egyes módszerek alkalmazásának módját és dilemmáit a pedagógia hétköznapi szituációiból merített és illusztrált esetekkel, mégis tudományos szemszögből vizsgálva. Így történik ez a nyílt és zárt végű kérdések alkalmazásának szemléltetése esetében is a kérdőívfejlesztés kapcsán, amelyet humoros példával szemléltet a szerző (p. 61).

A szerző az adatelemzés módszereinek bemutatása során elkülöníti a kvalitatív és kvantitatív adatelemzési eljárásokat, de rávilágít ezek vegyes alkalmazásának lehetőségére is. A fejezetben az olvasó aktuális információkat és gyakorlati segítséget találhat a kvalitatív tartalomelemzés új lehetőségeiről, például az Atlas.ti szoftver alkalmazásáról. A szerző nem mélyül el az egyes kvalitatív adatelemzési eljárások részleteiben, azok számára pedig, akik tovább elidőznének egy-egy témában, további irodalmat ajánl. Bővebben kerülnek azonban kifejtésre a fejezeten belül a kvantitatív adatelemzés leíró statisztikai és összehasonlító elemzési lehetőségei, amelyeket neveléstudományi kutatások publikációinak reprodukált ábráival és táblázataival illusztrál.

Az utolsó, ötödik fejezet a tudományos publikációk müfajait mutatja be, elhelyezve azok között a szakdolgozatot is. A jegyzet korábbi fejezeteinek tartalmára építve három szakdolgozati műfajt jelöl ki, és azok ismertetését követően gyakorlati tippeket is nyújt a szakdolgozatírás előtt álló pedagógus jelölteknek az alkotótevékenység megkezdéséhez, az acadamic writing, (Csíkos, 2020, p. 102) elsajátításához.

A tudományos, kutatói szemléletmód kialakítása céljából Csíkos Csaba jegyzete jó alapirodalma lehet pedagógusjelöltek kutatásmódszertan kurzusainak. Fő jellegzetességei a pedagógusképzésben való alkalmazhatóság szempontjából a következők:

- alapozó jelleg: összhangban a hazai tantervfejlesztés szemléletével a felsőoktatás szintjén is lehetővé teszi a spirális tudás konstruálást, amelynek első lépcsőfoka lehet a jegyzet tartalmának elsajátítása,

- autentikusság: pedagógusjelöltek számára pedagógiai szituációkon keresztül szemlélteti az egyes kutatásmódszertani fogalmakat, jelenségeket, stratégiákat,

- tömörség: egyetlen jegyzet formájában tartalmazza a neveléstudomány területén tanulók és kutatók számára legszükségesebb kutatásmódszertani ismereteket, 
- érthetőség: a jegyzet fejezetei könnyen olvasható k, amelyben a teoretikus szövegrészek folytonosságát humoros, szemléletes példák törik meg,

- hitelesség: a tömörség és érthetőség kritériuma önmagukban akár a hitelesség rovására is mehetnének, hiszen, ahogy minden tankönyv megírásakor, a kutatásmódszertan esetén is komoly dilemma, hogy hogyan egyszerüsíthető és rövidíthető le egy olyan téma, amely ennyire szerteágazó és ennyire komoly elméleti alapokra épül. A neveléstudomány kutatásmódszertanának alapjai címü könyv jó megoldást talált a problémára a fejezetekben történő kitekintésekkel, így a mủ egyaránt megállja a helyét a neveléstudományi kutatásokban jártas és kevésbé tapasztalt kutató(jelölte)k között is.

- aktualitás: a szakdolgozatírás és tudományos kutatások kivitelezése szempontjából napjainkban népszerű felületeket és eljárásokat mutatja be (például az Atlas.ti szoftver használata, a Google Tudós használata tudományos szövegek gyűjtésére és idézésére).

A könyv önálló feldolgozás által, valamint felsőoktatási kutatásmódszertani témájú kurzusok részeként beépítve egyaránt megállja a helyét.

A tudományos szemléletmód kialakítása érdekében a tudomány „művelésére” az abban való aktív és interaktív részvételre is szükség van, ebben pedig fontos szerepe lehet a könyvben is bemutatott gyakorlatközeli kutatási problémáknak és a humorral kiemelt tipikus hibák elkerülésének. Így például a 15. oldalon az olvasó megismerheti a tudományos megismerés jellemzői között az eredmények hasznosíthatóságának elvét, amelynek ellenpéldájaként a szerző a Citrom-Nobel-díjat ismerteti meg az olvasóval, ezzel biztosítva, hogy ezt a szempontot ne tévessze szem elől a kutató, hacsaknem az említett trófeára pályázik.

A bemutatott jegyzethez jól kapcsolhatók a kutatásmódszertanban való elmélyülést segítő aktív tanulási módszerek, úgy, mint akár a mozaik módszer egy-egy mintavételi eljárás előnyeinek megvitatására; esetmegbeszélések, viták, gondolattérképek a tudományos témák feltérképezésére, az önálló tanulás segítésére önellenőrző online tesztek, hipotézisek gyüjtése csoportokban adott kutatási kérdésekben.

A pdf formában megjelent könyv nagy előnye - kiváltképp a koronavírusjárvány idején elterjedt távoktatás, de akár a kialakulóban lévő blended-típusú képzések keretein belül is -, hogy a hallgatók számára a navigációt megkönynyíti a dokumentumon belüli keresés lehetősége, valamint az olvasást, megértést segítő kreatív tipológiai megoldások.

Összefoglalóan elmondható, hogy A neveléstudomány kutatásmódszertanának alapjai címü jegyzet praktikus minden olyan leendő pedagógusnak és a neveléstudomány iránt érdeklődőnek, aki korábban nem foglalkozott kutatással, de szakdolgozatának elkészítéséhez vagy a kutatói munkájához szeretné elsajátítani a tudományos megismerés és szövegalkotás fortélyait, valamint olyan pedagógusképzésben dolgozó oktatóknak, akik szeretnék felkészíteni hallgatóikat a tudományos kutatómunkára és a szakdolgozat vagy TDK-, OTDK-dolgozat írására. 


\section{Irodalom}

Csapó, B. (2005). Tanuló társadalom és tudásalapú oktatási rendszer. In Komlóssy, Á. (Ed.),Ismeretekés képességfejlesztés. A 42. Szegedi NyáriEgyetem Évkönyve (pp.5--21). Tudományos Ismeretterjesztő Társulat. Csapó, B. (2015). A kutatásalapú tanárképzés: nemzetközi tendenciák és magyarországi lehetőségek. Iskolakultúra, 25(11), 3-16. https://doi.org/10.17543/ISKKULT.2015.11.3

Csapó, B. (2020). Bevezetés: Neveléstudományi kutatás és a tudományos eredmények alkalmazása. Magyar Tudomány, 181(1), 3-10. https://doi. org/10.1556/2065.181.2020.1.1

Csíkos, Cs. (2020). A neveléstudomány kutatásmódszertanának alapjai. ELTE Eötvös Kiadó.

Falus, I. (1993, Ed.). Bevezetés a pedagógiai kutatások módszereibe. Keraban Kiadó.

Hercz, M. (2008). Professzionális tanárképzés az Európai Unióban 1. Finnország, Hollandia, Németország és az Egyesült Királyság példája. Iskolakultúra, 18(3-4), 96-123. http://real.mtak.hu/58940/1/9_EPA00011_iskolakultura_2008-3-4.pdf

Kraiciné Szokoly, M. (2009). Az élethosszig tartó tanulás kihívásai: középpontban a tanuló szervezet. Iskolakultúra, 19(12), 131; 143. http://www.iskolakultura.hu/ index.php/iskolakultura/article/download/20949/20739

Ollé, J. (2012). A tudás alapú társadalom iskolája. Információs Társadalom, 12(3), 7-14. https://doi.org/10.22503/inftars.XII.2012.3.1

Flick-Takács Nikolett: https://orcid.org/0000-0003-3201-5779 